\title{
State Clean Energy Practices: Renewable Fuel Standards
}

Technical Report NREL/TP-670-43513 July 2008

Gail Mosey and Claire Kreycik

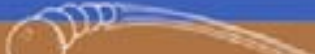




\section{State Clean Energy Practices: Renewable Fuel Standards}

\section{Gail Mosey and Claire Kreycik}

Prepared under Task No. IGST.8300 


\section{NOTICE}

This report was prepared as an account of work sponsored by an agency of the United States government. Neither the United States government nor any agency thereof, nor any of their employees, makes any warranty, express or implied, or assumes any legal liability or responsibility for the accuracy, completeness, or usefulness of any information, apparatus, product, or process disclosed, or represents that its use would not infringe privately owned rights. Reference herein to any specific commercial product, process, or service by trade name, trademark, manufacturer, or otherwise does not necessarily constitute or imply its endorsement, recommendation, or favoring by the United States government or any agency thereof. The views and opinions of authors expressed herein do not necessarily state or reflect those of the United States government or any agency thereof.

Available electronically at http://www.osti.gov/bridge

Available for a processing fee to U.S. Department of Energy and its contractors, in paper, from:

U.S. Department of Energy

Office of Scientific and Technical Information

P.O. Box 62

Oak Ridge, TN 37831-0062

phone: 865.576 .8401

fax: 865.576 .5728

email: mailto:reports@adonis.osti.gov

Available for sale to the public, in paper, from:

U.S. Department of Commerce

National Technical Information Service

5285 Port Royal Road

Springfield, VA 22161

phone: 800.553 .6847

fax: 703.605.6900

email: orders@ntis.fedworld.gov

online ordering: http://www.ntis.gov/ordering.htm 


\section{Table of Contents}

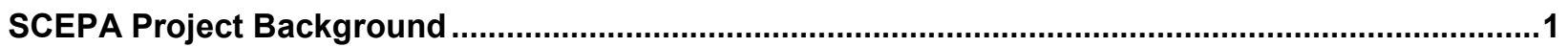

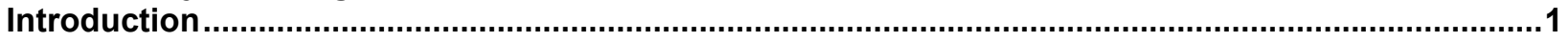

What is an RFS?

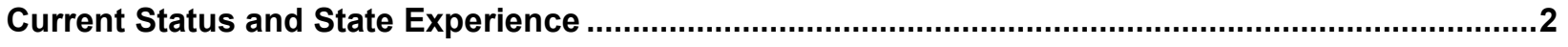

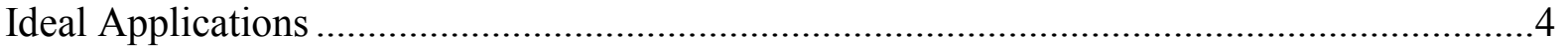

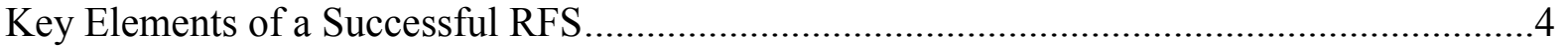

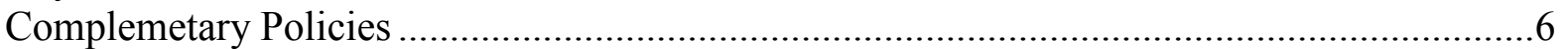

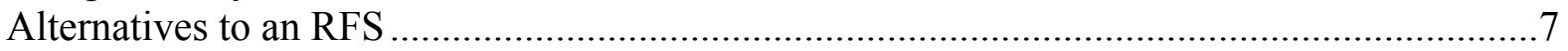

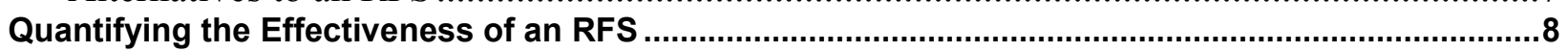

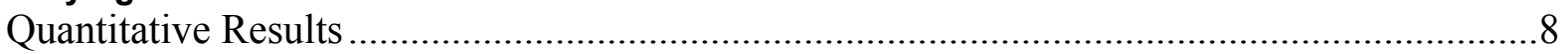

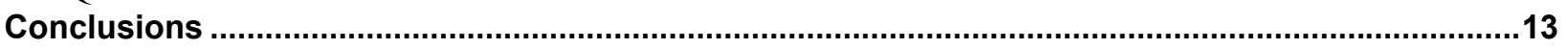

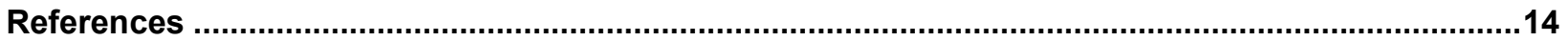




\section{SCEPA Project Background}

The State Clean Energy Policies Analysis (SCEPA) project is supported by the Weatherization and Intergovernmental Program within the U.S. Department of Energy's Office of Energy Efficiency and Renewable Energy. This project seeks to quantify the impacts of existing state energy policies, and to identify beneficial policy attributes and their potential applicability to other states. The goal is to assist states in determining which clean energy policies or policy portfolios will best accomplish their environmental, economic, and energy security goals. Experts from the National Renewable Energy Laboratory (NREL) and InterEnergy Solutions are performing this work, with state officials and energy policy experts providing extensive input and review. This report focuses on renewable fuel standards (RFS) policies, which are being analyzed as part of this project. For more information on the SCEPA project, access NREL's Applying Technologies Web site at http://www.nrel.gov/applying_technologies/scepa.html

\section{Introduction}

Renewable fuel standards (RFS) policies are a mechanism for developing a market for renewable fuels in the transportation sector. This flexible market-based policy, when properly executed, can correct for market failures and promote growth of the renewable fuels industry better than a more command-oriented approach. The policy attempts to correct market failures such as embedded fossil fuel infrastructure and culture, risk associated with developing renewable fuels, consumer information gaps, and lack of quantification of the non-economic costs and benefits of both renewable and fossil-based fuels.

When well-designed and executed, an RFS allows actors to develop least-cost solutions for fulfilling the mandate and can promote further innovation in the development of cost-effective fuels. Hawaii and Minnesota had experimented with RFS policies before 2006, when a national RFS was implemented. Since 2006, nine more state policies have been enacted. The state-level RFS legislation cited a positive impact on the rural economy; energy security by means of fuel diversification; reduction of dependence on foreign oil; and environmental benefits such as improved constituency health, air quality, and reduced $\mathrm{CO}_{2}$ emissions as important drivers.

This analysis uses available data to measure the impact of these policies against typical state policy drivers for energy efficiency and renewable energy: environmental impact, economic development, and energy security. Early evaluations are ambiguous on the environmental impact for both local and global pollutants, indicate a positive local economic development impact for states with feedstocks for fuel development, and show a relatively high impact on energy security through reductions in petroleum imports (Table 1).

Table 1. RFS Effects on State Policy Drivers

\begin{tabular}{|c|c|c|c|c|c|c|c|c|c|}
\hline & \multicolumn{4}{|c|}{ Economic Development } & \multicolumn{3}{|c|}{ Environmental } & \multicolumn{2}{|c|}{$\begin{array}{c}\text { Energy Securityl } \\
\text { Fuel Diversity }\end{array}$} \\
\hline Policy & $\begin{array}{l}\text { Value of } \\
\text { Industry }\end{array}$ & Net Job & GSP & $\begin{array}{c}\text { Purchase } \\
\text { Power }\end{array}$ & Local & Global & $\begin{array}{l}\text { Land } \\
\text { Use }\end{array}$ & $\begin{array}{c}\text { Imports } \\
\text { Offset }\end{array}$ & $\begin{array}{c}\text { Fuel } \\
\text { Diversity }\end{array}$ \\
\hline RFS & $\begin{array}{l}\text { High } \\
+\end{array}$ & $\begin{array}{c}\text { Med } \\
+\end{array}$ & $\begin{array}{c}\text { Med } \\
+\end{array}$ & $\begin{array}{c}\text { Med } \\
+\end{array}$ & $\begin{array}{c}\text { Low } \\
-/+\end{array}$ & $\begin{array}{l}\text { Low } \\
-/+\end{array}$ & $\begin{array}{l}\text { Med } \\
-/+\end{array}$ & $\begin{array}{l}\text { High } \\
+\end{array}$ & $\begin{array}{l}\text { High } \\
+\end{array}$ \\
\hline
\end{tabular}


While much research remains to accurately measure the impacts of state RFS policies, this report shows that states with a strong driver for energy security as well as a local resource for fuel production could benefit greatly from this type of policy.

\section{What is an RFS?}

A typical RFS requires that a certain percentage of transportation fuel in a geographic area be replaced by renewable fuels. Policies can be based on volume of total fuel sales and can target either gasoline sales or diesel sales. Policy mechanisms can be directed at several points along the supply chain (e.g., refiners, blenders, importers, distributors, and/ or retail sellers.) The market approach generally calls for a minimum volume of renewable fuels to be incorporated at these different levels each year. Depending on how the policy is structured, the regulated entity may have the option to purchase credits from other producers or distributors to meet the target.

\section{Current Status and State Experience}

Nine states have renewable fuel standards that have come into effect or are scheduled to come into effect at an arranged date or production capacity. Most of these states have enacted an ethanol mandate and/or a biodiesel mandate. Iowa officials have worded their RFS to include any renewable fuel that meets qualifications. Iowa will require the equivalent of $25 \%$ of all gasoline sales to come from renewable sources - sold as E10 (10\% ethanol and 90\% gasoline), biodiesel, E85-by 2019.

As of 2008, Hawaii requires $85 \%$ of all motor gasoline sold to contain $10 \%$ ethanol by volume. Policymakers first developed an RFS in 1994 to diversify the supply, hoping to protect consumers against oil price shocks. Hawaii imports all of its transportation fuels at high costs, so an RFS could be a strong market tool to stimulate in-state ethanol production as a cheaper way to meet the mandate. Plans for local ethanol production are behind schedule due to permitting delays and cost concerns. The five companies planning production facilities do not expect to come online until late 2008 or after (Honolulu Advertiser 2007 and ClearFuels Technology Inc. 2008).

In Louisiana, by 2015 or six months after the state produces the equivalent of 50 million gallons of ethanol per year (whichever comes first), all motor gasoline sales must contain $2 \%$ ethanol. By the same year or at 10 million gallons of production a year, $2 \%$ biodiesel must be used. Both Missouri and Montana will require all non-premium motor gasoline sales to contain $10 \%$ ethanol-Missouri by 2008 and Montana within one year of achieving 40 million gallons a year (mgy) production. There is no evidence that a trigger mechanism will reduce risk for investors. Such a policy may hinder the industry because the benefit of making infrastructure investments is uncertain.

On September 16, 2008, all motor gasoline sales in Oregon must contain 10\% ethanol by volume. By December 1, 2008, at least $2 \%$ of total gasoline sold in Washington State must be ethanol, and the director of Agriculture has the capability to adjust this percentage upward after review. Minnesota has expanded its standard from 10\% ethanol by volume in 1997 to the more stringent requirement of $20 \%$ ethanol by volume for all motor gasoline sales, and $2 \%$ biodiesel for all diesel sales. 
The following states have state-vehicle biodiesel requirements: Colorado, Kansas, and Maryland. New Mexico will require state vehicles to consume B5 (5\% biodiesel and 95\% gasoline) by July 1, 2010, a mandate that will commute to all diesel vehicles two years later. Tables 2 and 3 summarize state policies.

Table 2. State RFS Parameters and Goals for Ethanol

\begin{tabular}{|c|c|c|c|}
\hline State & Requirement & Date of & Details \\
\hline $\mathrm{HI}$ & E10 & 2008 & $\begin{array}{l}\text { At least } 85 \% \text { of gasoline sold must contain } 10 \% \text { ethanol by } \\
\text { volume }\end{array}$ \\
\hline IA & $\begin{array}{l}25 \% \text { fuels } \\
\text { renewable }\end{array}$ & 2020 & $\begin{array}{l}\text { Equivalent of } 25 \% \text { of all gasoline sales must come from } \\
\text { renewable sources (sold as E10, E85, or B1). }\end{array}$ \\
\hline$\overline{L A}$ & $\overline{\mathrm{E} 2}$ & $2015^{*}$ & $\begin{array}{l}\text { Total gasoline sales must contain } 2 \% \text { ethanol in } 2015^{*} \mathrm{OR} 6 \\
\text { months after in-state production reaches } 50 \mathrm{mgy} \text { ethanol. }\end{array}$ \\
\hline $\mathrm{MN}$ & E20 & 2013 & $\begin{array}{l}\text { Updated in } 2006 \text { to require } 20 \% \text { ethanol by volume for all } \\
\text { motor gasoline sales by } 2013 \text {. }\end{array}$ \\
\hline MO & $\begin{array}{l}\text { E10 (non- } \\
\text { premium) }\end{array}$ & 2008 & $\begin{array}{l}\text { Total non-premium motor gasoline sales must contain } 10 \% \\
\text { ethanol by volume. }\end{array}$ \\
\hline MT & $\begin{array}{l}\text { E10 (non- } \\
\text { premium) }\end{array}$ & $\begin{array}{l}\text { At } 40 \text { mgy } \\
\text { capacity }\end{array}$ & $\begin{array}{l}\text { Total non-premium motor gasoline sales must contain } 10 \% \\
\text { ethanol by volume. Within one year of achieving } 40 \text { mgy } \\
\text { production capacity for at least three months, the RFS will kick } \\
\text { in. }\end{array}$ \\
\hline $\mathrm{OH}$ & $\begin{array}{l}\text { State fleet } \\
\text { E85 }\end{array}$ & 2007 & $\begin{array}{l}\text { State vehicles owned or leased shall use } 60,000 \mathrm{~g} \text { of E85 per } \\
\text { year by January } 1,2007 \text {, with an increase of } 5,000 \mathrm{~g} \text { per year } \\
\text { after that. }\end{array}$ \\
\hline OR & E10 & 2008 & $\begin{array}{l}\text { Total gasoline sales must contain } 10 \% \text { ethanol by September } \\
16,2008 \text {. }\end{array}$ \\
\hline WA & E2 & 2008 & $\begin{array}{l}\text { By December } 1,2008 \text {, at least } 2 \% \text { of total gasoline sold must } \\
\text { be ethanol; the director of Agriculture may adjust this upward } \\
\text { after review. }\end{array}$ \\
\hline
\end{tabular}

Table 3. State RFS Parameters and Goals for Biodiesel

\begin{tabular}{|c|c|c|}
\hline State & $\underline{\text { Requirement }}$ & Date of Compliance \\
\hline $\mathrm{CO}$ & All state vehicles must be fueled with B20, subject to availability & 2007 \\
\hline IA & $\begin{array}{l}\text { B1 biodiesel sales can apply to the } 25 \% \text { renewable fuels } \\
\text { mandate }\end{array}$ & 2020 \\
\hline KS & $2 \%$ biodiesel or higher must be used in state vehicles & 2008 \\
\hline LA & Total diesel sales must contain $2 \%$ biodiesel (B2). & $\begin{array}{l}2015 \text { or } 10 \text { mgy } \\
\text { capacity }\end{array}$ \\
\hline MD & $\begin{array}{l}\text { At least half the state's diesel vehicle fleet must use a blend of } \\
\text { at least B5 }\end{array}$ & 2008 \\
\hline MN & Total diesel sales must contain $2 \%$ biodiesel (B2). & 2013 \\
\hline NM & $\begin{array}{l}\text { All diesel fuel used in state vehicles must be } 5 \% \text { biodiesel by } \\
\text { July } 1,2010 ; \text { and two years later, all sales in the state must be } \\
5 \% \text { biodiesel. }\end{array}$ & 2010,2012 \\
\hline
\end{tabular}




\begin{tabular}{|l|l|l|}
\hline OR & $\begin{array}{l}\text { All diesel fuel sold in the state must be blended with 2\% } \\
\text { biodiesel }\end{array}$ & 2008 \\
\hline WA & Equivalent of $2 \%$ of diesel sales must be biodiesel. & 2008 \\
\hline \hline
\end{tabular}

\section{Ideal Applications}

An RFS can be implemented anywhere in the United States, yet there are certain conditions that would make an RFS a good policy choice:

- Ample feedstocks (e.g., corn, crop residues, forest residues, primary and secondary mill residues, and urban wood waste). Resources should be considered by region due to the potential for interstate commerce. Figure 1 shows availability of lignocellulosic biomass for ethanol production, and Figure 2 shows availability of corn for grain-derived ethanol. Both figures illustrate the existing biorefineries.

- A commitment to biofuels production in-state.

- Public awareness of biofuels and a strong market penetration of flexible fuel vehicles (FFVs) or advanced fuel vehicles (AFVs); or a state-level or auto industry commitment to encourage the market adoption of FFVs or AFVs.

- The existence of a reformulated gasoline (RFG) requirement. The Clean Air Act requires that RFG be used in cities and counties with the worst smog pollution to reduce ozoneforming precursors. RFG is gasoline blended with oxygenates to burn cleaner and reduce smog-forming and toxic pollutants. Ethanol has replaced MTBE (methyl tertiary butyl ether) as the oxygenate of choice (EPA 2008).

\section{Key Elements of a Successful RFS}

In this analysis, an RFS policy is considered successful when it encourages development of leastcost solutions and spurs innovation in renewable fuels production and use. The development of renewable fuels production and use leads to immediate impacts on energy security, the state policy driver most affected by this policy type. The following design features can contribute to the effectiveness of the RFS:

- Imposing stringency requiring use of higher blends of ethanol or alternative fuels.

- Adopting an implementation plan that can ease measurement and verification $(\mathrm{M} \& \mathrm{~V})$ burdens and help ensure that the target is met.

- Avoiding trigger mechanisms because it is unlikely that they would reduce risk for investors.

- Ensuring flexibility in fuel requirements language to allow for adaptation and innovation that can lead to lowest-cost solutions and best practices.

- Implementing measurement and verification of environmental, economic, and fuel diversity benefits of the policy and ensuring it achieves the stated goals. 


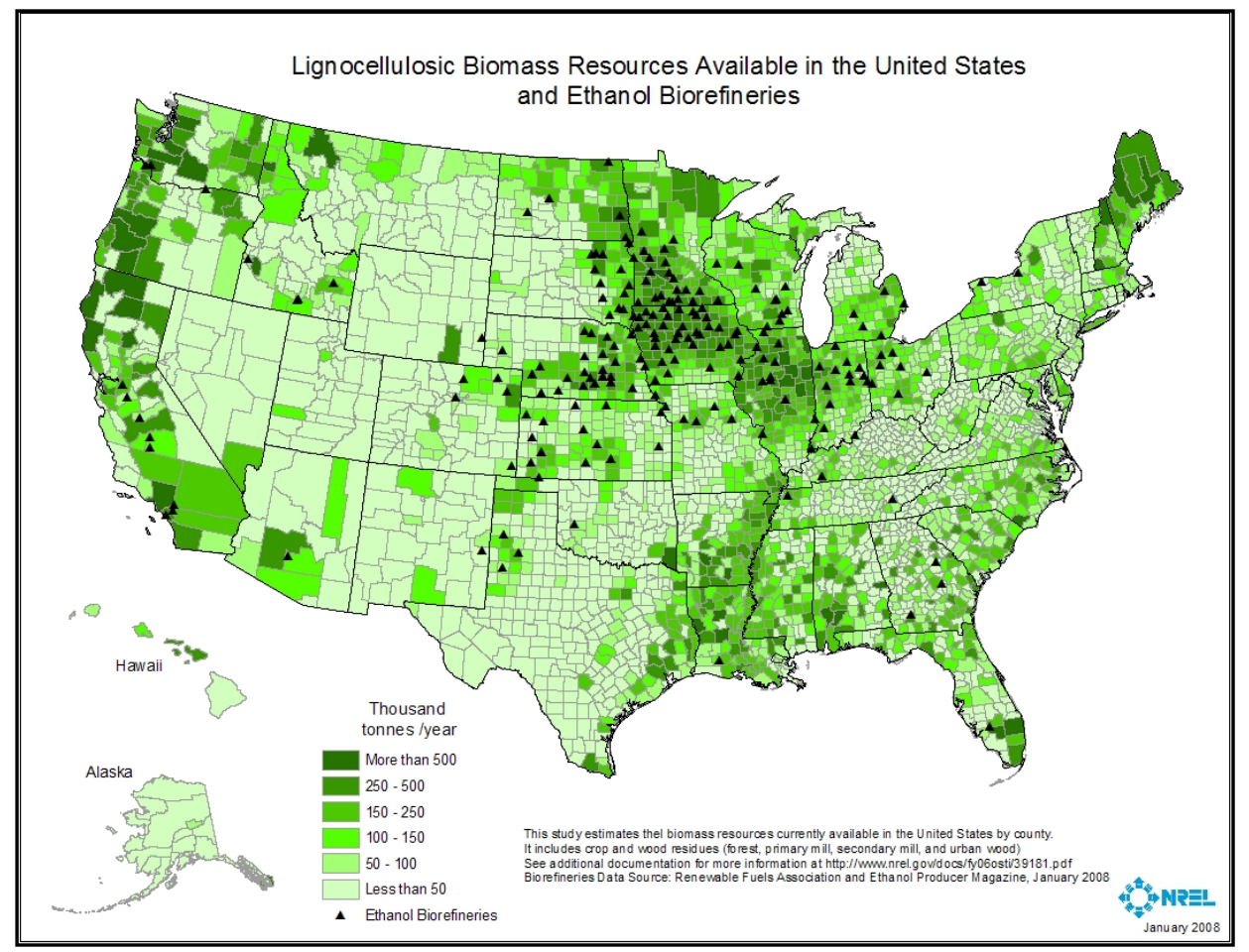

Figure 1. Existing biorefineries and resource availability of feedstock for lignocellulosic ethanol

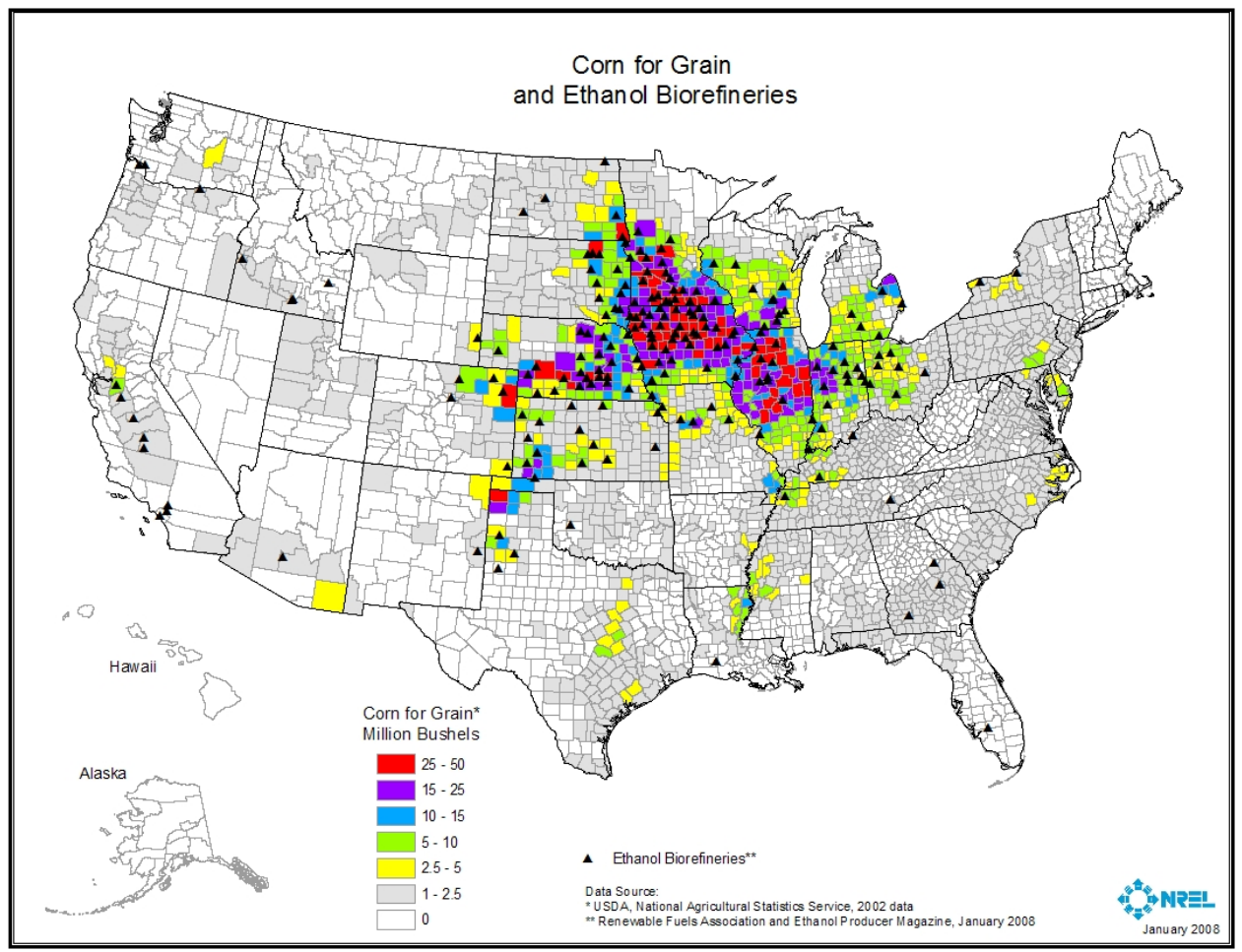

Figure 2. Existing biorefineries and resource availability of corn for grain-derived ethanol 


\section{Complementary Policies}

The free-market approach of an RFS encourages the lowest-cost solution for blending the new fuels into the mix, but does not directly create incentives for building the necessary infrastructure. Complementary policies are necessary for the success of an RFS policy. These policies can be directed toward biofuels production, distribution, and consumption. The use of higher blends of ethanol - such as E85 (85\% ethanol and 15\% gasoline) - and alternative fuels must be especially targeted, because it allows for greater market penetration of those fuels and will be necessary to meet some RFS goals. State policymakers can provide tax credits, subsidies, and grants at several points along the supply chain. They also can establish laws and regulations to ensure biofuels availability and use. The following policies may have significant impacts on the development and use of biofuels:

- Production incentives for advanced biofuels producers/refiners. Strong incentives for first movers in cellulosic ethanol or other innovative fuel refining could be offered in addition to existing incentives for corn ethanol production. New incentives could be modeled after the State of Minnesota, which offered early movers in the industry (qualified facilities that began ethanol production before June 30,2000) a production incentive or 20 cents per gallon of ethanol until 2010. ${ }^{1}$

- Biofuels promotion plans. Eight Midwestern states have established shared goals for lowcarbon biofuels production, E85 availability, and consumption of regionally produced biofuels (Midwest Governors Association 2008).

- Infrastructure grants that provide assistance to E85 retailers and biodiesel wholesale distributors. Such grants can include:

- matching or cost-share grants for retailers to upgrade or install new alternative fuel equipment.

- fee waivers for retailers to cover the costs of certification of dispensing equipment with an independent testing laboratory, or

○ cost-share grants for terminal distribution facilities for biofuels

- Tax credits for retail service stations that sell higher blends of alternative fuels. These should be separate from tax credits that might be available for retailers reaching their RFS for the year.

- Educational programs on E85 or other innovative fuels.

- Investment tax credits for distributors or retailers investing in equipment.

- Laws requiring retailers to house E85 dispensing equipment under the fuel awning and to prominently advertise to encourage E85 use.

- Lower excise taxes on renewable fuel products to reduce prices. ${ }^{2}$

- Laws requiring ethanol to be used to fulfill regional RFG requirements.

\footnotetext{
${ }^{1}$ The incentives and laws are summarized at the Advanced Fuels and Advanced Vehicles Data Center: Incentives and Laws, accessible at http://www.eere.energy.gov/afdc/incentives laws.html

${ }^{2}$ Minnesota's Alternative Fuel Tax, Statues 296A.07 and 296A.08
} 
- Alternative fuel use and vehicle-acquisition requirements. A use policy would require state agency fleets to use alternative fuel products like E85 and blends of biodiesel like B20 (20\% biodiesel and $80 \%$ diesel), when available.

- Financial incentives for FFV or AFV purchase, or modification of existing cars to handle renewable fuels.

\begin{abstract}
Alternatives to an RFS
An RFS establishes a mandate for the minimum amount of biofuels to be incorporated into a state's fuel supply. As such, an RFS reduces the risk associated with investing in biofuels infrastructure. Other policies, similar to those described in the previous section, can also address the drivers for an RFS. These policies can be adopted with or without a state-level RFS.
\end{abstract}

California's low-carbon fuel standard (LCFS) policy is an example of an alternative strategy that might achieve similar effects. An LCFS is an intensity target for the amount of carbon and other greenhouse gases (GHGs) emitted per unit of energy obtained from the fuel (i.e., gCO2e/MJ). The LCFS regulatory strategy is varied: it can require measuring all fuel consumption or partial amounts and regulation can take place at a number of points in the supply chain, most commonly at the level of oil refineries and importers. For an LCFS, some kind of valuing carbon intensity and trading system for carbon credits must be designed and implemented. The strategy may effectively encourage development of innovative low-carbon fuels and better transportation options.

An LCFS is similar to an RFS in that they both are market-based approaches dealing with the transportation energy sector. The goal of an LCFS is to reduce the carbon intensity of the transportation sector through three strategies: increasing the efficiency of vehicle technologies; reducing fuel-related GHGs (this can be achieved in several ways, one of which is increasing the use of renewable fuels); and, finally, decreasing the amount and use of vehicles and fuels by increasing the availability and use of alternative transportation (EIA 2007). California's goal is to reduce the carbon intensity of transportation fuels by $10 \%$ by 2020 (CARB 2007).

The LCFS mechanism may more directly approach the environmental driver of the RFS and provide for innovation of least-cost fuels. The current challenge with the LCFS is that there is uncertainty as to the environmental impact of biofuels, and the research question is being explored now. While an LCFS may address the environmental issues more directly than an RFS, this uncertainty can lead to design and implementation challenges that are unnecessary for states that are focusing primarily on energy security issues. However, in light of increasingly important environmental concerns at the state level, a singular focus on energy security without incorporation of environmental concerns is unlikely. 


\section{Quantifying the Effectiveness of an RFS}

States have published little data on actual impacts of RFS policies, but enhanced M\&V requirements could improve data availability. Minnesota and Iowa have published some information regarding the contributions of the biofuels industry to their economies. To evaluate the effectiveness of an RFS in light of the policy drivers, several analyses were conducted:

1) To quantify environmental impacts, a meta-analysis was done of several studies that characterize the emissions of different renewable fuel blends. We also looked at several projections of life-cycle or "well-to-wheel" carbon emissions.

2) Using various assumptions of how states will meet their RFS, an economic impact analysis was conducted using NREL's Job and Economic Development Impact (JEDI) model to quantify the impact of the RFS on states' economies.

3) A high-level analysis was done of how much crude oil can be expected to be offset by each state enacting an RFS in the year of compliance.

\section{Quantitative Results}

\section{Environmental Impacts}

There is uncertainty of the environmental benefits of biofuels. While a variety of studies have been completed using different parameters, the volume of research does not illustrate a clear understanding of biofuels impact. This is due partly to the large number of possible biofuels with different impacts as well as the large variation in geographic impact of different biofuels. It also should be noted that recently there has been a great deal of interest in the land-use impacts of biofuels production, specifically ethanol (Searchinger et al. 2008). While there are a number of ongoing studies and further research is pending, this section reviews the available literature for quantification. There is no doubt that analytic uncertainty in this area is high.

Most studies show that low concentrations of ethanol (the level in most current and proposed policies) decrease tailpipe emissions of carbon monoxide, particulates, and most air toxic emissions, as well as life-cycle emissions of carbon dioxide (Table 4). However, nitrogen oxide (NOx) emissions and other smog precursors appear to increase slightly (EPA 2007). More substantive testing must be performed before any final determinations are made about these impacts. These results are reflected in the summary impacts (Table 1) as Low-/+ for Local and Global impacts because of the potential offset of the positive and negative impacts.

There is no standard assessment protocol for biofuels life-cycle emissions. Researchers assess and weigh the GHG contribution from the variables of biofuels production and consumption differently. The emerging interest in the effects of land use on life-cycle emissions is casting some doubt on the value of biofuels, especially corn ethanol. The hypothesis is that the net carbon impact might be positive if energy crops replace food crops on arable land that was once used for food production. It has been postulated that the only way to ensure a net negative carbon impact is to grow energy crops on degraded land not suitable for agriculture. Until this can be 
further investigated, the summary impacts on Land Use were rated as a Med-/+ because of the uncertainty of the potential impacts (Table 1).

Table 4. Local Air Quality Impacts*

\begin{tabular}{|l|l||l|}
\hline Carbon Monoxide & Decrease & $\begin{array}{l}\text { An increase in ethanol use to 9.6 BGY represents } \\
\text { a 4\% decrease in carbon from the reference case }\end{array}$ \\
\hline NOx & Increase & $\begin{array}{l}\text { An increase to 9.6 BGY represents a 2\% increase } \\
\text { from the reference case }\end{array}$ \\
\hline $\begin{array}{l}\text { Volatile Organic } \\
\text { Compounds (VOCs) }\end{array}$ & Mixed & $\begin{array}{l}\text { Mixed, but it appears that on-road VOC emissions } \\
\text { decrease }\end{array}$ \\
\hline Benzene & Decrease & Up to 6\% \\
\hline Formaldehyde & Increase & Up to 3\% \\
\hline
\end{tabular}

*According to EPA, the amount of data evaluating the impact of ethanol and MTBE blending on direct emissions of particulate matter (PM) from gasoline-fueled vehicles is extremely limited so PMs are not addressed here. http://www.epa.gov/oms/renewablefuels/420f07019.htm\#impacts

\section{Economic Analysis}

Our analysis has shown that quantification of industry value, job creation, gross state product (GSP), and value of farm land and agricultural commodities indicate an RFS can benefit the local economy. The value of the industry output includes the value of the fuel itself, as well as value added from byproducts. The two most notable byproducts are high protein distillers dried grains (used for animal feed) from ethanol production and glycerin (used for many applications) from biodiesel production.

Minnesota was a first mover in the corn ethanol industry. The following impact estimation is an example of one state's experience with one particular biofuel. The Minnesota Department of Agriculture states that Minnesota produced 550 million gallons of ethanol from 16 plants in 2006. The state's net ethanol export was 290 million gallons or 53\%. The output impact and the employment impact since the beginning of the ethanol industry is summarized in Table 5 (Minnesota Department of Agriculture 2008).

A report by John Urbanchuck, the director of LECG (a global expert services company), quantified the impact of the new industry on the value of agricultural commodities and on Iowa's economy as a whole (Urbanchuck 2007). His study estimates the annualized impact of producing 1.7 billion gallons of ethanol and 115 million gallons of biodiesel on Iowa's economy (the capacity at year-end 2006). He estimated that the biofuels industry had added $\$ 8.2$ billion (or about 6.8\%) to Iowa's gross domestic product (GDP) at year-end 2006. Additionally, his analysis points to the generation of $\$ 1.8$ billion of household income for Iowa households, the creation of 53,000 jobs throughout the entire Iowa economy, and the generation of nearly $\$ 390$ million in state tax revenue. 
Table 5. Minnesota Ethanol Economic Impact

\begin{tabular}{|l|l|l|l|}
\hline Year & $\begin{array}{l}\text { Production } \\
\text { (Million Gallons) }\end{array}$ & $\begin{array}{l}\text { Output Impact } \\
\text { (\$ million) }\end{array}$ & $\begin{array}{l}\text { Employment Impact } \\
\text { (\# of Jobs) }\end{array}$ \\
\hline 1990 & 11 & 28.51 & 166 \\
\hline 1991 & 17 & 42.38 & 247 \\
\hline 1992 & 35 & 89.30 & 520 \\
\hline 1993 & 38 & 90.96 & 529 \\
\hline 1994 & 41 & 101.45 & 590 \\
\hline 1995 & 51 & 115.26 & 671 \\
\hline 1996 & 69 & 203.51 & 1,089 \\
\hline 1997 & 112 & 275.66 & 1,476 \\
\hline 1998 & 124 & 254.38 & 1,362 \\
\hline 1999 & 190 & 352.47 & 1,759 \\
\hline 2000 & 220 & 511.48 & 2,231 \\
\hline 2001 & 252 & 802.60 & 3,132 \\
\hline 2002 & 300 & 732.24 & 2,858 \\
\hline 2003 & 359 & $1,074.32$ & 4,008 \\
\hline 2004 & 400 & $1,476.02$ & 5,506 \\
\hline 2005 & 420 & $1,577.00$ & 5,883 \\
\hline 2006 & 550 & $2,766.61$ & 10,321 \\
\hline 2007 (Projected) & 620 & $3,067.80$ & 11,444 \\
\hline 2008 (Projected) & 1,000 & $4,948.61$ & 18,461 \\
\hline & & & \\
\hline
\end{tabular}

Economic impact from an RFS depends largely on production capacity of renewable fuels within a state. Impacts on jobs, earnings, and output directly reflect the ramp-up of biofuels production capacity and biofuels consumption resulting from an RFS. States with biofuels production will see the greatest impact from an RFS, particularly if they export biofuels; while states with low or no ethanol production may not be significantly impacted economically. A high-level analysis on economic impact was conducted using the Jobs and Economic Development Impact (JEDI) model for dry mill corn ethanol. JEDI is an input-output, spreadsheet-based model that estimates the economic impact from constructing and operating a dry mill corn ethanol plant. Users enter basic information about a project, including the state, location, year of construction, and size of the facility. The model then estimates project costs (i.e., specific expenditures), and economic impacts from jobs, earnings income (i.e., wages and salary), and output (i.e., value of production) as a result of the project.

Ethanol was chosen because it is the primary least-cost choice for current RFS implementation and because it can provide a rough proxy for other biofuel-related economic development. Assumptions were made about the incremental capacity required to meet the state-level RFS (no exports were considered), and JEDI was run assuming that dry mill corn ethanol plants were constructed and operated within each state to meet the incremental demand. Table 6 shows the 
direct, indirect, and induced ${ }^{3}$ impact on jobs, earnings, and output for those states with an RFS. Results are presented annually and may be multiplied by 20 years as a reasonable refinery life. These results clearly show a positive economic impact on jobs, earnings, and output from implementation of an RFS and are reflected in the summary impacts (Table 1) with a Med+ rating for Jobs, GSP, and Purchase Power impacts; and a High+ for Value of Industry because of the direct relationship between an RFS and an alternative fuel industry.

Table 6. Annual Economic Impacts of Meeting Incremental Ethanol Capacity for State-Level RFS, Construction Year 2008

\begin{tabular}{|c|c|c|c|c|}
\hline State & $\begin{array}{l}\text { Incremental } \\
\text { Ethanol } \\
\text { Capacity } \\
\text { Required for } \\
\text { RFS (million } \\
\text { gallons) } \\
\end{array}$ & $\begin{array}{c}\text { Annual } \\
\text { Jobs }\end{array}$ & $\begin{array}{c}\text { Annual } \\
\text { Earnings } \\
\$ M(2006)\end{array}$ & $\begin{array}{c}\text { Annual } \\
\text { Output } \\
\$ M(2006)\end{array}$ \\
\hline Hawaii & 107 & 1,000 & 33 & 59 \\
\hline Iowa & 218 & 1,321 & 27 & 128 \\
\hline Louisiana & 95 & 714 & 14 & 55 \\
\hline Minnesota & 1,000 & 6,526 & 151 & 598 \\
\hline Missouri & 376 & 3,581 & 54 & 226 \\
\hline Montana & 4 & 30 & 1 & 2 \\
\hline Washington & 100 & 568 & 17 & 56 \\
\hline Oregon & 224 & 1,392 & 38 & 130 \\
\hline Total & 2,124 & 15,133 & 334 & 1,256 \\
\hline
\end{tabular}

Note: NREL projected these impacts using the Jobs and Economic Development Impact Model (JEDI) for Dry Mill Corn Ethanol.

\section{Fuel Diversity and Fuel Security}

A renewable fuel standard has a direct effect on oil imports: The more endogenous transportation fuel that is consumed, the less that's imported for consumption. This consideration prompted a High+ rating for Imports Offset and Fuel Diversity in the summary impacts (Table 1). Because the energy content of ethanol is less than that of motor gasoline, the offset is not one to one. We have done a rough calculation of how many gallons of motor gasoline would be displaced by the RFS in the first year of compliance in each state. Because of the heat content of the two fuels, for every gallon of motor fuel offset, approximately 1.62 gallons of ethanol is required. This analysis uses ethanol as the fuel in the indicator because ethanol is commonly used and technologically feasible today. We also estimated how this number is related to the number of barrels of crude oil imported. The number is based on the assumption that between half and two-thirds of a barrel of oil is converted to motor gasoline. We found that in the first year of these RFS policies, 21 million barrels of crude oil (or 1.3 billion gallons of motor gasoline) will be offset as a direct effect of the RFS (Table 7).

\footnotetext{
${ }^{3}$ Direct impact refers to the changes that occur in the industries to which the direct final-demand (i.e., purchase of goods and services) change is made. Indirect impact refers to the changes in inter-industry purchases resulting from the direct final-demand (i.e., purchase of goods and services) changes. Induced impacts refer to the changes that occur in household spending as household income increases or decreases as a result of the direct and indirect effects from direct final-demand (i.e., purchase of goods and services) changes.
} 
These numbers represent what each individual state can expect to see as a fuel offset in the first year of compliance. Enacting an RFS has an obvious benefit in fuel diversity and security of a state; furthermore, in-state production of biofuels will add to the state's energy independence.

Table 7. Million Barrels Crude Oil Offset in First Year of Compliance for States with an RFS

\begin{tabular}{|c|c||c|c|}
\hline $\begin{array}{c}\text { States with } \\
\text { policies in } \\
\text { place }\end{array}$ & $\begin{array}{c}\text { Crude oil offset } \\
\text { (million barrels) }\end{array}$ & $\begin{array}{c}\text { Motor gasoline } \\
\text { offset (million } \\
\text { gallons) }\end{array}$ & Year \\
\hline HI & 1 & 66 & 2008 \\
\hline IA & 2 & 134 & 2020 \\
\hline LA & 1 & 59 & 2015 \\
\hline MN & 10 & 617 & 2013 \\
\hline MO & 3 & 232 & 2008 \\
\hline MT & $<1$ & 2 & 2015 \\
\hline OR & 2 & 138 & 2008 \\
\hline WA & 1 & 62 & 2008 \\
\hline Total & 21 & 1,310 & \\
\hline
\end{tabular}

Note: NREL-projected. 


\section{Conclusions}

While limited in direct quantitative results due to data challenges, this analysis allows for qualitative conclusions about the impacts of an RFS policy. Because the policies are so new, there is limited information on how different policy variables affect the success of an RFS. States' experiences with the RFS will be very different depending on geography, resources, and the goals that are set. For example, different levels of incentives for production and distribution will be necessary in different states due to cost differentials, transportation distances, and other variables.

An important consideration in developing an RFS is to safeguard against technological lock-in. There is interest in the development of innovative fuels from the federal R\&D sector, and an RFS with an eye toward innovative fuels may have more of an impact, especially in terms of creating positive environmental impact and affecting that policy driver.

Refinement of policy drivers may impact the development of future policies. As more information is known about the environmental impacts of biofuels, states may choose to revise their RFS to meet another target. Additionally, industry experience, the future of agricultural subsidies, and evaluation of economic value of the industry may reorder such a policy on the state's priority list. As states' goals change, so will their attitudes toward biofuels and other alternative fuels.

The key findings of this report are that an RFS will be most successful in a policy environment with energy security as the primary driver. However, there are several unknowns regarding biofuels, including environmental impact, and those may be increasingly important in the event of a carbon-restrained policy environment. In addition, complementary policies that create incentives for innovation and infrastructure have been critical to the success of RFS policies in several states.

Research and historical evidence of states that have RFS policies show that enacting an RFS is a good way to support local industry and diversify fuel supply. The environmental benefits of an RFS need to be verified if reduction of emissions is the driver of the highest importance. Fuelflexibility language in the proposal can prevent technological lock-in and will encourage innovation in alternative fuel options. 


\section{References}

California Air Resources Board (CARB). (2007). "A Low-Carbon Standard for California," accessed February 2008 at http://www.arb.ca.gov/fuels/lcfs/lcfs_uc p2.pdf

ClearFuels Technology Inc. (2008). Accessed at http://www.clearfuels.com/

Energy Information Administration (EIA). (2007). "Transportation Sector Energy Use by Mode and Type," Annual Energy Outlook, accessed February 2008 at http://www.eia.doe.gov/oiaf/aeo/supplement/pdf/sup tran.pdf

Environmental Protection Agency (EPA). (2007). "Regulatory Impact Analysis of the RFS." http://www.epa.gov/otaq/renewablefuels/420f07019.htm

Environmental Protection Agency (EPA). (2008). "Reformulated Gas." http://www.epa.gov/oms/rfg.htm

The Honolulu Advertiser. (2007). "New Kauai ethanol plant delayed" http://the.honoluluadvertiser.com/article/2007/Oct/18/bz/hawaii710180342.html; and "Enough water for ethanol?" http://the.honoluluadvertiser.com/article/2006/Oct/08/ln/FP610080363.html

Midwest Governors Association. (2008). "Energy Security and Climate Stewardship Platform Plan," accessed at http://www.midwesterngovernors.org/

Minnesota Department of Agriculture. (2007). Accessed at http://www.mda.state.mn.us/renewable/ethanol/productionimpact.htm

Searchinger, T.; Heimlich, R; Houghton, R.A.; Dong, F.; Elobeid, A.; Fabiosa, J.; Tokgoz, S.; Hayes, D.; Yu, T.H. (2008). "Use of U.S. Croplands for Biofuels Increases Greenhouse Gases Through Emissions from Land Use Change." Science. February 2008.

Urbanchuck, John M. "Contribution of the biofuels industry to the economy of Iowa." Prepared for the Iowa Renewable Fuels Association. February 2007.

Wind Powering America. (2008). Accessed at http://www.eere.energy.gov/windandhydro/windpoweringamerica/econ_project_search.asp. 


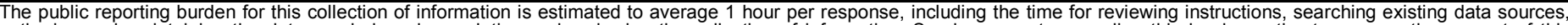

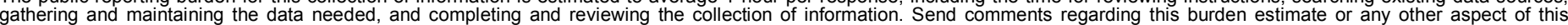

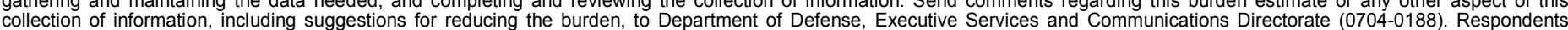

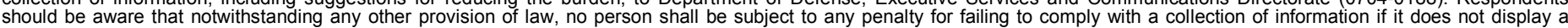

currently alid

PLEASE DO NOT RETURN YOUR FORM TO THE ABOVE ORGANIZATION.

\begin{tabular}{l|l|l|l} 
1. REPORT DATE (DD-MM-YYYY) & 2. & REPORT TYPE & 3. DATES COVERED (FrOm - TO)
\end{tabular} July 2008

Technical Report

4. TITLE AND SUBTITLE

State Clean Energy Practices: Renewable Fuel Standards 5a. CONTRACT NUMBER

DE-AC36-99-G010337

5b. GRANT NUMBER

5c. PROGRAM ELEMENT NUMBER

5d. PROJECT NUMBER

NREL/TP-670-43513

5e. TASK NUMBER

IGST.8300

5f. WORK UNIT NUMBER
7. PERFORMING ORGANIZATION NAME(S) AND ADDRESS(ES)

National Renewable Energy Laboratory

1617 Cole Blvd.

Golden, CO 80401-3393

9. SPONSORING/MONITORING AGENCY NAME(S) AND ADDRESS(ES)
8. PERFORMING ORGANIZATION REPORT NUMBER

NREL/TP-670-43513

10. SPONSOR/MONITOR'S ACRONYM(S) NREL

11. SPONSORING/MONITORING AGENCY REPORT NUMBER

12. DISTRIBUTION AVAILABILITY STATEMENT

National Technical Information Service

U.S. Department of Commerce

5285 Port Royal Road

Springfield, VA 22161

13. SUPPLEMENTARY NOTES

14. ABSTRACT (Maximum 200 Words)

The State Clean Energy Policies Analysis (SCEPA) project is supported by the Weatherization and

Intergovernmental Program within the Department of Energy's Office of Energy Efficiency and Renewable Energy.

This project seeks to quantify the impacts of existing state policies, and to identify crucial policy attributes and their potential applicability to other states. The goal is to assist states in determining which clean energy policies or policy portfolios will best accomplish their environmental, economic, and security goals. For example, renewable fuel standards (RFS) policies are a mechanism for developing a market for renewable fuels in the transportation sector. This flexible market-based policy, when properly executed, can correct for market failures and promote growth of the renewable fuels industry better than a more command-oriented approach. The policy attempts to correct market failures such as embedded fossil fuel infrastructure and culture, risk associated with developing renewable fuels, consumer information gaps, and lack of quantification of the non-economic costs and benefits of both renewable and fossil-based fuels. This report focuses on renewable fuel standards policies, which are being analyzed as part of this project.

\section{SUBJECT TERMS}

energy efficiency; renewable energy; policy; state policy; stakeholder drivers; economic development; environmental; energy security; renewable fuel standards; RFS

\begin{tabular}{|c|c|c|c|c|}
\hline \multicolumn{3}{|c|}{ 16. SECURITY CLASSIFICATION OF: } & \multirow{2}{*}{$\begin{array}{l}\text { 17. LIMITATION } \\
\text { OF ABSTRACT } \\
\text { UL }\end{array}$} & \multirow{2}{*}{$\begin{array}{ll}\text { 18. NUMBER } & \text { NUM } \\
\text { OF PAGES }\end{array}$} \\
\hline $\begin{array}{l}\text { a. REPORT } \\
\text { Unclassified }\end{array}$ & $\begin{array}{l}\text { b. ABSTRACT } \\
\text { Unclassified }\end{array}$ & $\begin{array}{l}\text { c. THIS PAGE } \\
\text { Unclassified }\end{array}$ & & \\
\hline
\end{tabular}

19a. NAME OF RESPONSIBLE PERSON

19b. TELEPHONE NUMBER (Include area code) 